\title{
International Cooperation in the Twenty-first Century: Familiar Problems and New Challenges*
}

\author{
HAROLD K. JACOBSON \\ Jesse Siddal Reeves Professor of Political Science, University of Michigan
}

The creation and proliferation of international organizations of various sorts, increasing economic intendependence, the spread of democracy, and the strong leadership played by the United States all worked positively together to facilitate international cooperation during the second half of the twentieth century, overcoming to a great extent the familiar problem of 'cooperation under anarchy.' But humankind is confronting new challenges as well, arising from the shift in power relations among nation-states and the rise of new issues that call for global attention. One of the most prominent issues is the protection of environment. It is unclear bow easily the formulas that have proved to be so successful in bringing about international cooperation in the twentieth century can be applied to the new challenges. If a series of organized responses to the issue of climate change as shown in the completion and implementation of the Framework Convention on Climate Change (FCCC) is any indication, however, the international community seenis to have succesffully begun to confront them. The relative promptness of action taken by the international community the manner in which the issue is negotiated where the principle of equity was directly addressed, the comprehensiveness of the Treaty's scope, and responsible behavior of the states of the world all point to broad optimism about international cooperation in the twenty-first century. 
7 he second half of the twentieth century has brought unprecedented progress to 1 humankind. There has been: relatively little organized violence, especially interstate violence; incredible economic growth; steady progress toward greater respect for human rights; and, the launching of efforts to preserve and protect the human environment, the earth system. International cooperation has made this progress possible. Can this cooperation be extended into the twenty-first century so that this progress will continue and be deepened and strengthened?

One might answer by suggesting that during the second half of the twentieth century humankind mastered the intricacies of international cooperation, and humankind merely needs to continue applying the techniques that have proved so rewarding in the past fifty years. Yet the future is more complex. Continuing international cooperation will undoubtedly involve dealing with familiar problems, but it also will involve addressing new challenges. The familiar problems are those that stem from the difficulty of achieving international cooperation in the nation-state system, the problem that is neatly summed up in the phrase, "achieving cooperation under conditions of anarchy" (Oye 1986). The new challenges are those that stem from the shifting distribution of power among nation states and from the new issues that must be addressed in the global arena, especially those relating to the protection of the environment, issues that paradoxically arise from the success that humankind has achievod in other fields.

I will address both the familiar problems and the new challenges. Then, I will take climate change as a case study to argue that the international community has successfully begun to confront the new challenges. First, we need to briefly describe the familiar problems, review the ideas of political philosophers about how these problems might be overcome, and describe how they have been addressed in the second half of the twentieth century. How has the remarkable progress that has been achieved through international cooperation been brought about? Next, I will introduce the new challenges and ask how easily the formulas that have proved so successful in bringing about international cooperation can be applied to these new challenges. Then, I will examine the issue of climate change. Finally, I will speculate in broad general terms about international cooperation in the twenty-first century.

\section{FAMILIAR PROBLEMS}

\section{The Sovereign State System}

Sovereignty is the legal principle on which the contemporary global political system is based. The doctrine of sovereignty lodges supreme political authority in territorially defined units, and states. According to the doctrine of sovereignty the government of a state is free from external control, there is no higher authority, and its writ is supreme within its territorial boundaries.

Sovereignty was introduced as the defining principle for allocating political authority in 1648 with the Peace of Westphalia. As this new system was being put in place, allocating 
political authority to the sovereign state proved to be a superior way to promote economic growth and provide security (Spruyt 1994). The system of sovereignty was gradually extended from Europe to other areas, and with the end of colonialism in the second half of the twentieth century the entire world was encompassed in a system of sovereign states.

Soveteignty has brought great advantages to humankind. It has brought order within nation states and provided means for controlling violence. By facilitating specialization and commerce within the borders of states, it has contributed to economic growth. It has provided a framework for the development of democratic systems of government.

But, sovereignty has also caused problems. Because there is no higher authority, states must rely on their own armed forces for self-defense. Since states tend to feel secure only when they have a margin of superiority over their rival forces, the system of self-help for defense stemming from sovereignty has a propensity to induce arms races: each state will try to have more forces than its rival, producing an endless spiral of accumulations of armaments, a spiral that could slip out of control and result in violent conflict. This process has appropriately been named the "security dilemma," signifying that states' efforts to gain security can actually result in their having less security (Herz 1950).

A system based on sovereignty also has a propensity toward a less than optimal allocation of economic production. Given the importance of productive capacity to military power, states are pressed to shape their economies in the direction of autarky. States will want to ensure that they have within their territories all of the elements of production that are essential to the pursuit of war. Thus, they will want to be as self-sufficient as possible in agriculture and have their own heavy industries, especially aircraft, automobile, and chemical facilities. Completely free trade has always been blocked by considerations of self-sufficiency.

A system based on sovereignty also has had difficulties dealing with egregious violations of human rights by states. Since there is no authority above the government of a state, should the government decide to violate human rights, there is no authority to which citizens could appeal nor one which could compel the government to behave more responsibly.

Finally, a system composed of sovereign states is likely to fail to deal with issues involved in the management of commons such as the oceans and the atmosphere. All states can profit from exploiting the commons, and no single state alone can protect them, so the tendency will be for commons to be overexploited.

\section{Achieving Cooperation Under Conditions of Anarchy}

Even before sovereignty was introduced as the defining characteristic of the international system, political philosophers had thought about how some of the dangers inherent in a system based on this principle could be mitigated and how international cooperation could be achieved (Hemleben 1943). International organizations were a key ingredient in this prescription. 


\section{International Organizations}

It was a long time, however, before international organizations became a salient feature of the international system. The first international governmental organizations (IGOs) came into being in the nineteenth century. The first general purpose, universal membership IGO, the League of Nations, was created in 1919. Only in the years since the conclusion of World War II did the total number grow to its present size of more than 1,100, a total comprised of over 300 traditional IGOs and over 800 emanations of these IGOs (Shanks, Jacobson, and Kaplan 1996).

The prescription to create international organizations is in some ways simply a logical deduction derived from the concept of an international system based on sovereignty. For cooperation among sovereign states to occur, having a forum in which the details of cooperative agreements could be worked out would be helpful and could even be a necessity. Recent scholarship, however, has clarified why this should be the case.

IGOs provide a way of creating an information-rich environment. The IGOs make it possible to gather data that are comparable because they have been collected according to common criteria. IGOs also easily disseminate data. Because secretariats play a role in the collection, compilation, and dissemination of data, and members of secretariats are at least to some extent disconnected from national governments, IGOs introduce a certain pressure toward objectivity in the handling of data. IGOs also provide forums where views can be exchanged. Although these contributions are frequently unheralded, they are among the more important things that international organizations do. Having an information-rich environment is an important first step toward achieving cooperation. In such an environment problems can be identified and the consequences of action or inaction foreseen.

IGOs provide places where agreements can be reached. Their periodic meetings provide a stimulus to action. Governments become mobilized when there is a meeting deadline. IGOs have regular procedures for making decisions so one can get to the issues at stake immediately rather than having to settle procedural issues first.

In short, and in the jargon of social science, IGOs reduoe the transaction costs involved in reaching cooperative agreements (Keohane 1984). If states had to set up mechanisms for gathering data each time they desired to address a problem and then determine the procedures for reaching an agreement, much effort would have to be devoted to these tasks, and agreements would be more difficult to reach and rarer.

International organizations also facilitate solving classic problems that frequently inhibit cooperation. "Commons," resources to which access cannot be denied and for which consumption by one does not preclude consumption by others, ate frequently over-utilized and destroyed (Olson 1968). Single actors could only make an insignificant contribution to solving the problem by limiting their consumption of the resource, but they could maximize their short-term rewards by exploiting the resource as fully as they could. An agreement by all parties to limit consumption is essential, and IGOs provide settings in which such agreements are possible. IGOs also increase "the shadow of the future." Many international problems appear to resemble the classic " prisoners dilemma"; that is 
if actors cooperated they could each benefit, but if one defected while the other cooperated, the reward for the one who defected would be higher than would have occurred if both had cooperated. The temptation for defection thus is high in games that are played only once, but if garnes are played repeatedly actors will learn that the other side can defect also, in which case both players lose, but mutual cooperation will maximize longterm benefits. IGOs provide assurances that games will be repeated. They increase the "shadow of the future," a crucial stimulus to international cooperation (Axelrod 1984).

These generalizations about the contribution of IGOs to providing an informationrich environment and overcoming classic problems of cooperation underlie the success of the International Monetary Fund and the General Agreement on Tariffs and Trade/the World Trade Organization in bringing about economic disarmament; particularly widespread currency convertibility and minimal level tariffs. They also explain the successes achieved so far in dealing with elements of the earth system such as the Mediterranean Sea and the oceans (Haas 1990; Mitchell 1994).

Creating international organizations, however, was only one part of the prescription for achieving international cooperation in a system of sovereign states. The full prescription offered by classical liberal political philosophers has always had two other major components, increasing economic interdependence and promoting and strengthening democracy.

\section{Economic Interdependence}

The prescription for economic interdependence is based on the assumption that people throughout the world seek economic betterment and that they judge their governments by the progress they make or not make toward this goal. It assumes that greater specialization and trade will yield a larger product. International cooperation makes specialization and interdependence possible. International economic cooperation also has a selfreinforcing effect. The greater the level of interdependence, the greater the reluctance to break cooperation for fear of diminishing the economic product and the greater the pressure for expanding cooperation so that the economic product can grow even larger.

\section{Democracy}

Democracy tends to make governments more accountable to public opinion and the public will. The prescription to promote and strengthen democracy was designed to make governments responsive to the broad popular desire for material betterment and thus to encourage them to engage in international cooperation. Moreover, democracy depends on collaboration among individuals with divergent interests, it takes conflicts of interest as expected natural occurrences and provides ways of resolving or managing these conflicts. The philosophers who thought that promoting democracy would be a way of facilitating international cooperation believed that skills learned dealing with conflicts of interest within states could be transferred to resolving and managing conflicts of interest among states.

During the half century since the end of World War Il, international governmental 
organizations have proved to be powerful instruments for promoting democracy. The proclamation by the United Nations of the Universal Declaration of Human Rights in 1948 launched a drive for the protection of human rights and dignity and set a standard again which all governmental conduct can be judged. The spread of democracy, which was especially dramatic in the nineteen-eighties and early nineteen-nineties, has contributed to IGOs functioning more effectively. Again, as in the case of economic interdependence, there has been a mutually reinforcing effect.

\section{The International Distribution of Power}

There are of course other explanations and prescriptions for international cooperation than those invoked by classical liberalism. Realists from Machiavelli through Morgenthau have focused intensively on power relations. One school has argued that an equilibrium distribution of power, or a balance of power, would make a crucial contribution to facilitating cooperation, especially on security issues among adversaries. Another school has seen hegemony by a single state as being an important component in bringing about international cooperation.

There can be no doubt that power relations are an important factor in international cooperation, though reality seems to be more complex than either of the views that were mentioned in the preceding paragraph. While a balance of power could facilitate arms control agreements between rival camps by convincing both sides that neither could gain through the use of force, it is unlikely to promote economic cooperation between them even though it may promote economic cooperation within each camp. Hegemony can enforce submission, but coerced submission is not voluntary cooperation. On the other hand, a hegemonic state can give incentives to reluctant partners in cooperation and bear a disproportionate share of the costs of providing common goods.

However arguments about the distribution of power are interpreted, there can be no doubt that the United States has played a crucial role in promoting international cooperation in the second half of the twentieth century. Many of the institutions that exist were the result of American planning and initiatives. The United States has provided the largest single financial contribution to most international institutions to which it has belonged. American participation has been an indispensable ingredient of virtually all of the successful efforts at international cooperation, and American leadership has been a basic component of most of them. The United States could not have made the contribution that it has to international cooperation in the second half of the twentieth century had it not been for its extraordinary economic and military power. The United States contribution has been relatively benign and positive because the United States has not had territorial ambitions, has been more interested in absolute than in relative economic gains, and has believed that it would be better off the more democracies there were.

\section{Cyclical or Secular Change?}

All of these elements international organizations, economic interdependence democrati- 
zation, and American leadership have contributed to the remarkable progress that has been made in the second half of the twentieth century. No single factor by itself could account for what has happened, but in combination they have brought about a decline in violence, greater material welfare, improved respect for human rights and dignity, and initial efforts to improve the human environment. The progress achieved during this period is remarkable, and it seems to have followed a relatively straight, upward trajectory. Can this trajectory be projected into the next century? Will the cooperation that has been achieved in the second half of the twentieth century continue uninterrupted into the twenty-first century? Will the instruments to facilitate cooperation that were forged in the twentieth century work in the twenty-first?

History suggests caution in optimistically believing that cooperation will automatically be extended. Another promising period of international cooperation occurred during the middle of the nineteenth century. There was rudimentary international cooperation in the creation of such international organizations as the Central Commission for the Navigation of the Rhine, the International Telegraph Union, and the Universal Postal Union. Economic interdependence increased and economic growth resulted in material betterment. Democracy spread. There was relatively little inter-state violence. But these positive trends slowed and eventually were reversed in the events leading to World War I. Despite a promising start toward international cooperation after the Versailles peace settlement, international cooperation collapsed and World War II erupted (Carr 1949; Holborn 1951). Unprecedented violence occurred, the world product diminished, and human rights were violated in previously unimaginable ways.

We must ask if the international cooperation that has occurred in the second half of the twentiech century has achieved sufficient momentum, staying power, and adaptability that it has become irreversible or whether the world has once more experienced a zenith of conperation. Is the change that has occurred in the second half of the twentieth century cyclical or is it secular? These questions cannot be answered with certainty. We can, however, address them. To do so requires looking into the future, trying to understand what the twenty-first century will be like. It seems clear that international cooperation will face new challenges.

\section{NEW CHALLENGES}

The new challenges that international cooperation will face in the twenty-first century can be subsumed in two broad categories, the changing distribution of power and new issues.

The distribution of power among states is changing at an impressively rapid pace. Because industrialization began in Europe and the state system was started there, relations among Eutopean states tended to dominate international relations from the seventeenth through the nineteenth centuries and this continued in many ways into the twentieth century as the North Atlantic basin became the predominant focus of international activity. Since the nineteen-eighties, however, the North Adlantic basin has been surpassed by 
the Pacific basin as locale for the greatest amount of international commerce. We are witnessing the rise of Asia. The economic progress in Asia has been remarkable. At first this progress was concentrated in smaller states, but in the last two decades it has included Asia's two giants, the two most populous countries in the world, China and India. If present trends continue, sometime in the twenty-first century China's economy will surpass that of the United States. Since a state's economic base is the foundation on which its military power is built, China will have the potential for military superiority. India will not be far behind China.

The new issues that must be addressed stem from humankind's success, particularly in achieving continual marerial betterment. Industrialization and economic modernization have contributed to many things including improved health care, which has led in the second half of the twentieth century to the most rapid increase ever in the world's human population. Population growth will continue through much of the twenty-first century. Rapid population growth combined with rapidly increasing standards of living has contributed to unprecedented pressures on the earth system. More people have required more and more food, and the products they have sought have required more and more resources. Human activities have always forced change in the earth system; what is novel is the pace and scale of these changes. Examples of anthropogenically forced global environmental changes include acid deposition (or acid rain as it is more commonly known), desertification, stratospheric ozone depletion, and climate change.

We must examine both of these challenges in greater detail.

\section{The Changing Distribution of Power and the Rise of Asia}

The distribution of power among states has always changed. The United States replaced Britain as the dominant power in the early twentieth century if not before then. Germany challenged Britain's dominance toward the end of the nineteenth and the beginning of the twentieth century. Earlier Spain, Portugal, the Netherlands, and France all enjoyed periods of global dominance, and countries like Sweden enjoyed periods of regional dominance. All were challenged and ultimately surpassed. The problem is that shifts in dominance have often been marked by violent conflict. The period in which the power of the second most powerful state has approached that of the first has been particularly perilous. Even when violent conflict has been avoided, international cooperation has been difficult. And this dynamic process of challenge to dominance resulting in violence apparently occurs within regions as well as globally.

The rise of the giants of Asia, China and India, must be a source of concern. Will the process of one or the other or both surpassing the economic might of the United States be managed peacefully? Or will it lead to violence? How will China and India manage their own relations? How will they manage their relations with other Asian states such as Japan, Indonesia, Bangladesh, and Pakistan? Quite apart from the potentiality of conflicts related to the changing power of these states relative to those in other regions and among themselves, there are ample sources of conflict among them over territory and resources.

Some analysts have argued that one should not expect the same dynamic processes that 
have characterized relations among European states to apply to relations between Asian and ocher states or among Asian states (Mahbubani 1995). These analysts maintain that conflict is dealt with differently in Asian cultures than it is in European cultures and that this will carry over to inter-state relations.

Other analysts argue that it is the structure of the state system that causes the danger (Waltz 1979; Organski and Kugler 1980). They argue that the dynamic processes of dominance and challenge with the potential for violence are inherent in a system based on the legal doctrine of sovereignty.

Undoubredly there is wisdom in both positions. A system that relies on self-help for gaining military security has the "security dilemma" built into it. But states react differently to the security dilemma. While Asian states have sources of conflict about control over territory and resources, none of the Asian states appears to have the universal aspirations that some European states have had in the past.

Whatever the ultimate truth, it is apparent that with the rise of Asia, attention must be given to insuring that foreseeable shifts in the distribution of power globally and regionally do not erupt in violence. The world must accommodate, adapt to, and manage the rise of Asia.

To some extent the classic prescriptions have already been applied in efforts to address potential problems stemming from the rise of Asia. Asian states are firmly engaged in international governmental organizations, they are part of the global trading system, and democracy has spread in Asia. The United States has also contributed to maintaining a balance of military forces in the region.

But the prescriptions have not been applied in Asia in the same extent that they have been in the North Atlantic region. China has not yet regained membership in the General Agreement on Tariffs and Trade/the World Trade Organization. The web of international governmental organizations among Asian states is much less dense than it is among North Adlantic states. Interdependence among Asian states is less than it is among North Atlantic states. And the proportion of non-democratic regimes is higher among Asian states.

The challenge posed by the rise of Asia to continuing the upward trajectory of international cooperation is to find ways of applying more fully the classic prescriptions for international cooperation to Asian states, to determine if new and different prescriptions are needed, and if so to apply them.

Having considered the changing distribution of power, let us turn now to the new issues, those stenmming from global environmental change.

\section{New Issues Posed by Global Environmental Change}

Expressed as a mathematical equation, the number of people on earth times the level of economic development that they have, modified by the type of technology that they employ, constitutes the anthropogenic pressure that forces global environmental change. Demographic and economic change have always produced local effects. Increasingly they are producing transnational, regional, and even global effects. Acid deposition in one 
country can be the result of sulfur emissions in another. Emissions of carbon dioxide, wherever they occur contribute to the greenhouse effect that causes climate change. The pace of demographic and economic change that has occurred in the second half of the twentieth century is unprecedented, and this has resulted in unprecedented pressures on the earth system, pressures that in the most alarmist view could threaten the habitability of the earth.

Global environmental change calls for global action to mitigate to the extent possible the pace and scale of change and to adapt to those environmental changes that will inevitably occur. Even changes that produce primarily local effects can be a source of global concern if the local effects are widespread, cannot be addressed by local authorities, or have longer-term consequences that can spread through commerce and other interactions. Phenomena that occur through global processes and have global effects such as stratospheric ozone depletion and climate change must be addressed globally.

At first glance, achieving international cooperation to deal with global environmental change might seem merely to require further application of the prescriptions that have been so successful in bringing about international cooperation in the second half of the twentieth century in the security and economic areas. Are not the problems caused by global environmental change simply "commons" problems, problems that humankind has learned to deal with? They are indeed commons problems, but they are far more complex than any that have been dealt with successfully on the international level.

They are more complex because they involve domestic issues extensively. During the second half of the twentieth century international cooperation contributed to security through limiting local wars, creating confidence building measures, installing arms control, and bringing about a measure of disarmament. It also contributed to economic growth and prosperity by bringing about economic disarmament and thereby making trade possible. The tasks that led to these contributions all involve issues that are traditionally within the realm of international affairs.

Recall, however, the formula that explains the anthropogenic pressures that force global environmental change. The key components are demographic and economic change, issues that are quintessentially domestic. It is true that international organizations have been concerned with population issues for several decades, but they have never tried to regulate population growth. IGOs have sought to promote economic growth and have provided financial and technical assistance for this purpose, but again they have never attempted to regulate this economic growth. It will challenge traditional modes of international cooperation to deal with issues that are as central to the domestic affairs of states as population and economic growth.

In addition, serious issues of equity arise. Developing countries, especially the Asian states that have economies that are growing rapidly insist that efforts to deal with global environmental change should not freeze the status quo or even seriously limit their growth. The governments of these states argue that current environmental problems are artributable to the actions of the developed states and that it would be grossly unfair as a consequence of trying to deal with environmental issues to prevent developing states from attaining the level of material welfare that the developed states presently enjoy, 
They maintain that international cooperation to deal with the issues posed by global environmental change must be premised on the continued economic growth of developing economies.

This premise has been widely accepted, but integrating it into a framework for action is complicated. Given the size and rapid growth of the Asian economies, particularly China and India, it will be a matter of only a few decades before they are the principal contributors of the emissions and other polluting actions that cause global environmental change. Even if the developed countries reduced their level of economic activity, which they are not about to do, environmental change would continue because of the increased activities of developing countries. Developed countries will not act if they believe that the developing countries will seek to be free riders.

Developing countries, on the other hand, have strong interests that may well compel them to take steps to deal with global environmental change. They are more vulnerable to the effects of global environmental change than developed countries. They have a higher proportion of their populations engaged in agriculture, and agriculture contributes proportionately more to their gross domestic products than is the case with developed countries. Agriculture is more vulnerable to the effects of global environmental change than other major sectors of economies. Developing countries are also particularly vulnerable to such effects of global environmental change as sea-level rise. Self-interest therefore should stimulate developing countries to cooperation.

What progress has been made so far? Let us now turn to the case of climate change to see how these broad points have played out in a specific case.

\section{CLIMATE CHANGES}

Although Svante Arrhenius first put forth the theory that rising concentrations of carbon dioxide would lead to global warming in 1896 , international action to attempt to deal with the implications of this theory began only in 1979 when the First World Climate Conference was held (Rowlands 1995). Since then, the pace of negotiations has been relatively rapid. In 1990 the Intergovernmental Panel on Climate Change (IPCC) issued its first scientific assessment (Houghton, Jenkins, and Ephraums 1990) and the Second World Climate Conference was held.

The IPCC report and the Second World Climate Conference laid the scientific foundation for negotiations toward a framework treaty. The IPCC stated in its report that it was confident of the existence of a natural greenhouse effect and that emissions resulting from human activities were substantially increasing the atmospheric concentrations of greenhouse gases (carbon dioxide, methane, chlorofluorocarbons, and nitrous oxide). The IPCC predicted that if greenhouse gas emissions continued at their then present level the increased concentration of long-lived gases in the atmosphere would result in an increase in the global mean temperature of about $0.3^{\circ} \Delta$ Celsius per decade. It concluded that during the decade from 1980 to 1990 carbon dioxide had contributed 55 percent of the greenhouse gases to the change in radiative forcing; chlorofluorocarbons, 24 , percent: 
methane, 15 percent; and nitrous oxide, 6 percent. Carbon dioxide emissions result primarily from fossil fuel combustion and land use changes.

Under IPCC's "business as usual" scenario, greenhouse gas emissions would increase following historically-based trajectories. Greenhouse gas emissions are essentially a product of the number of people times the level of development, the level of development being modified by the energy intensity of development and the carbon intensity of energy use. Population in virtually all countries, even most of those that are classified as developed, is predicted to increase, and virtually all governments ate committed to economic growth.

The IPCC report and the Second World Climate Conference, whete the report was discussed and its conclusions reaffirmed, provoked concern and also made it obvious how complicated dealing with climate change would be. Governments nevertheless responded with what in the history of international diplomacy can only be regarded as alacrity.

\section{The Framework Convention on Climate Change (FCCC)}

The first session of the Intergovernmental Negotiating Committee for a Framework Convention on Climate Change (INC) was held in February 1991, and the convention was completed and opened for signature on May 9, 1992. In June 1992, at the United Nations Conference on Environment and Development (UNCED), 154 states and the European Union (EU) signed the United Nations Framework Convention on Climate Change (FCCC, United Nations 1992). More have signed since then. The treaty came into effect in March 1994 after fifty states had acceded to it. As of mid-1996, there were 145 parties to the convention.

The objective of the treaty is "stabilization of greenhouse gas concentrations in the atmosphere at a level that would prevent dangerous anthropogenic interference with the climate system" (FCCC, Article 2). In acceding to the treaty, states accept the first principle of the treaty which is that "The Parties should protect the climate system for the benefit of present and future generations of humankind, on the basis of equity and in accordance with their common but differentiated responsibilities and respective capabilities" (FCCC, Article 3). All parties to the treaty undertake a number of commitments (FCCC, Article 4) to meet the treaty's objective. Though these commitments are stated in general terms in the framework convention, they are to be made more specific through legal instruments that will be negotiated, a process that was launched at the first Conference of the Parties (COP-1) in Berlin in 1995.

The FCCC is one of the most far-reaching treaties ever negotiated. It is the most serious effort so far to deal with the human dimensions of global environmental change. Since greenhouse gas (GHG) emissions are the result of so many aspects of modern life, becoming a party to the treaty commits states to subjecting almost all aspects of their economic activities to some form of international scrutiny and supervision. The legal instruments that will be negotiated under the FCCC will have profound impacts on national economies. The requirement that these legal instruments should contain specific commitments that would be framed "on the basis of equity and in accordance with [the par- 
ties'] common but differentiated responsibilities and respective capabilities" will be challenging to the intellectual talents and diplomatic skills of the parties.

Although the process of negotiating legal instruments under the FCCC has started, and some form of an agreement will be produced in 1997 or shortly thereafter, this will just be a beginning. The first instruments will involve commitments only for developed country parties, or in more formal terms, Annex I countries. Eventually a global bargain will have to be struck involving all parties. And, as dealing with ozone depleting substances has shown, commitments as complex as these will undoubtedly need to be modified and supplemented over time (Benedick 1991; Brenton 1994; Haas, Keohane, and Levy 1993). The process of negotiating instruments to implement the Framework Convention on Climate Change will be long-lasting and probably continual.

At the first meeting of the Conference of the Parties to the Framework Convention on Climate Change (COP-1) in Berlin in March 1995, the parties agreed that the convention's provisions relating to the commitment of developed countries to take measures aimed at returning their greenhouse gas emissions to 1990 levels by the year 2000 were not adequate. They adopted the Berlin Mandate which established a process to enable parties to take appropriate action for the period beyond 2000 , including a strengthening of developed country commitments through the adoption of a protocol or other legal instrument. A negotiating group, the Ad-hoc Group on the Berlin Mandate (AGBM), was created to prepare the instrument. It was agreed that work should be completed as early as possible so that the results could be adopted at COP-3 which will meet in Kyoto, Japan in December 1997. This process of strengthening and deepening the commitments will continue well into the future.

\section{Questions that Must be Addressed in Implementing the FCCC}

As they move to implement the Framework Convention on Climate Change, the parties to the convention must address several questions.

Although the o3.bjective of the treaty is clearly specified stabilization of greenhouse gas concentrations in the atmosphere at a level that would prevent dangerous anthropogenic interference with the climate system what level this should be is left to be determined in the negotiations about implementation as are the means of achieving the objective. Paragraph 4 of Article 3 in the FCCC states that:

The Parties have a right to, and should, promote sustainable development. Policies and measures to protect the climate system against human-induced change should be appropriate for the specific conditions of each Party and should be integrated with national development programs, taking into account that economic development is essential for adopting measures to address climate change.

Thus economic development should continue. It is clear that parties will legitimately interpret the need to stabilize greenhouse gas concentrations in the light of their own concepts about sustainable development. 
A primary issue in the negotiations consequently will be the level of greenhouse gas concentrations that should be the target toward which action should be directed. Whatever target is chosen, several other issues then arise.

Parties to the convention have been dealing with all sources of, and sinks and reservoirs for greenhouse gas emissions as the treaty requires (FCCC, Article 2, Paragraph 3). But, because carbon dioxide constitutes more than half of the greenhouse gas emissions, and chlorofluorocarbons are already controlled by the Vienna Convention for the Protection of the Ozone Layer, the Montreal Protocol, and subsequent agreements, parties to the FCCC could decide to concentrate on $\mathrm{CO}_{2}$ emissions in their early efforts to strengthen commitments.

Several modalities for controlling greenhouse gas emissions, or policies and measures as the treaty terms them (FCCC, Article 4, Paragraph 2 (a)), are conceivable. There could be quantitative limitations on emissions: parties could be told to reduce their emissions or limit the growth of these emissions. Another possibility would be to set a global limit for emissions, then allocate this global limit among parties, giving each party a certain number of permits or entitlements. Still another possibility would be to limit gneenhouse gas emissions through product standards; for instance, automobiles would be required to meet a certain standard of efficiency. Internationally agreed taxes would be another possibility. If parties had permits or entitlements, they could be tradable or non-tradable.

Another issue is the unit to which agreed limitations should apply. In the case of the European Union, limits could be set for the EU (some refer to this as the bubble concept) or for its individual member states. The FCCC permits parties to jointly implement policies and measures (FCCC, Article 4, Paragraph 2 (a)). Thus, a country that had high costs associated with emission limitations could jointly implement activities limiting emissions with a party that had low costs and both would get credit for the limitation. Parties will have to take positions on the extent to which activities jointly implemented (AJI) will be permirted and counted and which parties should be permitted to participate in such activities.

All of these issues will be at stake in the negotiations. Thus parties must have positions on:

1. the level of GHG concentration considered acceptable and achievable;

2. the GHGs to which a particular agreement should apply;

3. the policies and measures to limit GHG emissions;

4. if there were permits or entitlements, whecher or not they would be tradable; and

5. the units to which policies and measures should apply and the extent to which AJI should be allowed and counted.

The first issue, the level of GHG concentration sought, while it involves judgments about political feasibility and economic costs and benefits, has substancial natural science components. Natural science is also involved in the second and third issues. How policy makers interact with natural scientists in particular countries will be an important factor shaping the positions they adopt. 
All of these issues will have to be negotiated in light of the requirement in Article 3 of the FCCC that agreements under the treaty be achieved "on the basis of equity and in accordance with their common but differentiated responsibilities and respective capabilities." How can this requirement be fulfilled? As a practical matter, there is no objective way to establish parties' responsibilities or equity. The IPCC, however, has outlined the most common definitions (Banuri, Goran-Maler, Grubb, Jacobson, and Yamin 1996). Equity is important not only because of the treaty requirement, but also because the perceived equity of obligations has been demonstrated to be one of the most important factors in facilitating compliance with international environmental accords (Jacobson and Brown Weiss 1995).

The treaty requires that "the developed country Parties should take the lead in combating climate change and the adverse effects thereof" (FCCC, Article 3), and the Berlin mandate specifically involves strengthening the commitments of the Annex I countries. Annex I countries include twenty-four developed countries, eleven European countries undergoing the process of transition to a market economy, and the European Union.' Fifteen of the developed countries are members of the European Union.

Although the strengthened commitments negotiated under the Berlin mandate will apply only to Annex I parties, all parties to the convention can participate in the AGBM, and most do. The reason for the AGBM being open to all parties is that the Annex I parties did not want to create a precedent so that when it came time for the non-Annex I countries to consider strengthening their obligations, there would be a case for excluding Annex I parties from the deliberations. Thus the positions that other parties take in the Berlin mandate discussions could affect the positions that Annex I parties take. And it seems clear that unless the developing countries take some steps to acknowledge the seriousness of the problem of climate change and indicate a willingness to in due course undertake serious commitments, the developed countries will be reluctant to go very far.

As the negotiations proceed, parties to the FCCC have been doing the serious preparatory work that will be required to implement the treaty. They have been conducting inventories of sources of and sinks for greenhouse gas emissions. Pilot projects have been undertaken to see how activities jointly implemented will work. National plans to limit emissions are being prepared.

\section{The FCCC and Steps Taken Thus Far: A Cause for Optimism?}

How should the FCCC and the steps that have been taken so far to implement it be interpreted? Do the treaty and the actions of the parties provide a basis for optimism that new challenges for international cooperation can be met? I feel that they do. First, action was taken relatively prompty. The FCCC came into force less than a decade and a half after a scientific consensus was achieved that a problem existed. Second, the treaty is very

Annex I includes: Asıstralia, Austria, Belarus, Belgium, Bulgaria, Canada, Czechoslovakia, Dentnark, European Economic Community, Estonia. Finland, France, Germany, Greece, Htungary, Iceland, Ireland, Italy. Japan. Latvia, Lithuania, l.uxembourg, Netherlands, New Zealand, Norway, Poland. I'orrugal, Romania. Russian Federation, Spain. Sweden. Swirzerland, 'Turkey. Ukruine, United Kingdom, and the Unired Srates of Aquerica. 
comprehensive and is a sophisticated and subtle instrument. Third, the treaty directly addresses the issue of equity. Finally, to date the states of the world have behaved responsibly. All of the important contributors of greenhouse gas emissions are parties to the treaty. The developed countries are taking the lead in taking actions to limit greenhouse gas emissions as the treaty requires them to. And the developing countries, including China and India, are contributing constructively to the negotiating process.

This positive assessment notwithstanding, it must be acknowledged that the broad consensus that has been achieved and the international cooperation that has occurred are all preliminary steps to taking action to mitigate climate change. The real tests are yet to come. The first indication of how serious governments really are about trying to mitigate climate change and what steps they are willing to take to modify their economic policies will be the actions they take at the third Conference of the Parties of the FCCC in Kyoto in December 1997. COP III merits careful monitoring.

\section{INTERNATIONAL COOPERATION IN THE TWENTY-FIRST CENTURY}

Does this single case study provide a basis for broad optimism about international cooperation in the twenty-first century? To some extent I believe that it does. The First and Second World Wars and the collapse of the world economy in the nineteen twenties and thirties provided a powerful stimulus to successful international cooperation that occurred during the second half of the twentieth century. There was wide agreement among humankind that those catastrophes must not be repeated. What is encouraging about the actions that have been taken concerning climate change is that serious steps have already been taken to address the problem simply on the basis of clear scientific analysis. Catastrophes of the magnitude of the two world wars and the great depression have not been needed to stimulate action. The fact that Asian states have played important roles in the development of the climate change regime is encouraging. There is a basis for arguing that humankind is learning how to use international cooperation to avoid dangers inherent in the international system and in the level of economic development that has been achieved, and that the Asian states that will play such an important role on the international stage in the twenty-first century are very much part of this learning process.

There is another way in which the case study of international cooperation concerning climate change provides a basis for optimism. In our review of the fruits of international cooperation in the second half of the twentieth century, we concluded that international cooperation had been enormously successful in solving problems that stemmed from inter-state interactions. Humankind has made great progress in this respect. But as the twentieth century draws to a close it seems increasingly the case that for further progress to be made in reducing organized violence, advancing material betterment, and promoting respect for human rights and dignity, international cooperation will have to pay greater and greater attention to intra-state issues. Ethnic conflict within states causes great violence and can spill over and result in violence among states. Domestic regulations 
have become far greater obstacles to trade than tariffs and quotas. Human rights issues have always been domestic. Because climate change involves issues that are so quintessentially domestic, that humankind is making progress in dealing with it provides hope that it will be able to deal with other issues that have strong domestic components.

It may be that humankind is learning to enjoy the benefits and also avoid dangers of a system based on sovereignty (Chayes and Chayes 1995).

\section{REFERENCES}

Axelrod, Robert. 1984. The Evolution of Cooperation. New York: Basic Books.

Banuri, Tariq, Karl Goran-Maler, Michael Grubb, Harold K. Jacobson, and Farhana Yamin. 1996. "Equity and Social Considerations." In Climate Change 1995: Contribution of Working Group III to the Second Assessment Report of the Intergovernmental Panel on Climate Change, eds. James P. Bruce, Hoesung Lee, and Erik F. Haires. Cambridge: Cambridge University Press.

Benedick, Richard Ellior 1991. Ozone Diplomacy: New Directions in Safeguarding the Planet. Cambridge. MA: Harvard University Press.

Brenton, Tony 1994. The Greening of Machiavelli: The Evolution of International Environmental Politics. London: Earthscan.

Carr, Edward Hallett. 1949. The Twenty Years' Crisis, 1919-1939. London: Macmillan.

Chayes, Abram and Antonia Handler Chayes. 1995. The New Sovereignty: Compliance with International Regulatory Agreements. Cambridge, MA: Harvard University Press.

Haas, Peter M., Robert O. Keohane, and Marc A. Levy. 1993. Institutions for the Earth: Sources of Effective International Environmental Protection. Cambridge, MA: The MIT Press.

Haas, Peter M. 1990. Saving the Mediterranean: The Politics of International Environmental Cooperation. New York: Columbia University Press.

Hemleben, Sylveser John. 1943. Plans for World Peace Through Six Centuries. Chicago: University of Chicago Press.

Herz, John. 1950. "Idealist Internationalism and the Security Dilemma." World Politics 2(1), 157-180.

Holborn, Hajo. 1951. The Political Collapse of Europe. New York: Alfred A. Knopf.

Houghton, John T., Geoffrey J. Jenkins and J. J. Ephraums. 1990. Climate Change: The IPPC Scientific Assessment, Report Prepared for IPCC by Working Group I. Cambridge: Cambridge University Press.

Jacobson, Hatold K. and Edith Brown Weiss. 1995. "Strengthening Compliance with International Environmental Accords: Preliminary Observations from a Collaborative Project." Glabal Governunce 1(2), 119-148.

Keohane, Robert O. 1984. After Hegemony: Cooperation and Discord in the World Political Economy. Princeton: Princeton University Press.

Mitchell, Ronald B. 1994. International Oil Pollution at Sea: Environmental Policy and Treaty Compliance. Cambridge, MA: The MIT Press.

Mahbubani, Kishore. 1995. "The Pacific Way." Foreign Affairs 74(1), 100-111.

Olson, Mancur, Jr. 1968. The Logic of Collective Action: Public Goods and the Theory of Groups. New York: Schocken Books.

Organski, A.F.K., and Jacek Kugler. 1980. The War Ledger. Chicago: University of Chicaga Press. 
Oye, Kenneth, ed. 1986. Cooperation Under Anarchy. Princeton: Princeton University Press.

Rowlands, Ian H. 1995. The Politics of Global Aimospheric Change. Manchester: Manchester University Press.

Shanks, Cheryl, Haxold K. Jacobson, and Jeffrey H. Kaplan. 1996. "Inertia and Change in the IGO Population." International Onganization 50(4), 593-628.

Sprinz, Detlef. 1993. "The Impact of International and Domestic Factors on the Regulation of Acid Rain in Europe: Preliminary Findings." Journal of Environment and Development 2(1), $37-61$.

Sprinz, Detlef and Tapani Vaahtoranta. 1994. "The Interest-Based Explanation of International Environmental Policy." International Organization 48(1), 77-105.

Spruyt, Hendrik. 1994. The Sovereign State and Its Competitors. Princeton: Princeton University Press.

United Nations. 1992. United Nations Framework Convention on Climate Cbange, May 9, USTLA.

Waltz, Kenneth N. 1979. Theory of International Politics. Reading, MA: Addison-Wesley. 